\title{
Post-socialism and "ordinary" tourism: New Belgrade
}

\author{
Milos Nicic and Sanja Iguman
}

\begin{abstract}
Purpose - The purpose of this paper is to examine the emerging practices of the "tourism of the ordinary" in the wider frame of post-socialist transformation of Serbia's capital city - Belgrade. By sourcing the inspiration in cultural studies and classics of the studies of the ordinary, focus is directed to the patterns of tourism consumption of practices, places and people that do not fall in the category of tourism attraction. The attention is drawn to New Belgrade (Novi Beograd in Serbian), residential part of Belgrade built predominantly after the Second World War. New Belgrade lacks proper tourism infrastructure, commoditized attractions and consumerable tourism experiences on a large scale. Nevertheless, this part of the city is slowly becoming explored by tourists individually or in organized walking or cycling tours. Visits to New Belgrade are most often connected to alternative or hip visitors and have the allure of both urban exploration and cultural practice, as the tours are offered by specialist architectural organizations or individual guides. By introspecting the case of New Belgrade, this paper attempts to address the prospect that ordinary exist only in relation to the attraction and that its appeal comes from the fact that what is ordinary to someone is attraction to another.

Design/methodology/approach - As far as specific approach is concerned, some archival and librarian materials have been analyzed in order to map the territory that is being researched (New Belgrade) and to frame the significance of potential heritagisation (Harrison, 2013) on the built environment and its territory. Further, relevant websites and both primary and secondary resources have been consulted. This mostly refers to the websites of Tourist Organization of Belgrade (TOB) and the Institute for the Protection of Cultural Monuments in Belgrade as two most relevant bodies connecting the urban fabric of the city and its tourism valorization.

Findings - In this paper, the authors have tried to demonstrate how tourism of the ordinary might be conducted in urban environment that lacks no tangible resources, whose physical physiognomies are not insignificant and which, in another, alternative tourism regime might be considered attractions. However, in the specific set of characteristics spanning from contested past to ambiguous contemporary valorization, New Belgrade remains an uncharted part of the city for much of the mainstream tourism, leaving its charms for very few visitors, most often engaged in interest of the "ordinary."

Originality/value - Although Belgrade is experiencing steady rise in numbers regarding tourist arrivals, length of stay and on-site expenditure, New Belgrade is nowhere to be seen on the map of tourism offer, as per Belgrade's Tourism Organization. TOB's official web page, at the time this piece is written, in the section Attractions, mentions nothing regarding New Belgrade. Among 13 entries - 12 are historic sites of more than a century behind them and one is a lake and outdoor destination.
\end{abstract}

Keywords Tourism, Architecture, Post-socialism, New Belgrade, Ordinary

Paper type Case study

\section{Introduction}

In the era in which certain places, traditionally associated with mass tourism and established attractions are experiencing different forms of crisis, ranging from safety and security issues (Hall et al., 2012), sustainability challenges (Mowforth and Munt, 2015), crowdedness (Peručić and Puh, 2012), rampart development and gentrification (Gotham, 2005; Maitland, 2010; Gant, 2016), the "ordinary" locations are gaining a significant attention from both demand and supply side of the tourist market (Gravari-Barbas and Jacquot, 2016; Novy and Huning, 2008; Andersson, 2007; Butler, 1990). This trend is bringing tourism to a new phase, in which the main stakeholders who create the touristic offer are not the mainstream and traditional ones, but rather
Milos Nicic is based at Center for Cultural studies, Faculty of Political Sciences, University of Belgrade, Belgrade, Serbia. Sanja Iguman is based at Universita degli Studi di Bergamo, Bergamo, Italy.

Received 7 January 2018 Revised 30 April 2018 16 July 2018

Accepted 31 August 2018

(C) International Tourism Studies Association

This paper forms part of a special section "New cultures of urban tourism". 
the alternative and more "ordinary" actors such as NGOs, citizens' associations, students' organizations and neighborhood and/or individual initiatives. In this paper, we will refer to "traditional" touristic offer as the one associated to the official and large agencies and operators, following the path of established attractions. "Alternative" touristic offer is in this paper the one created and provided by local individuals, NGO associations and alternative actors in general, oftentimes not directly associated with tourism.

This paper sources the theorethical and conceptual understandings of ordinary and everyday from the classical texts of cultural studies and sociology (Lefebvre, 1947; Williams, 1958; Hoggart, 1957) and brings it into the dialog with tourism studies. The phenomenon in which tourist resort are becoming regular towns (Stock and Lucas, 2012), accomodation offer moves away from traditional forms (hotels, motels, etc.) to peer-to-peer accomodation facilitated by Airbnb (Guttentag, 2015), so change the spaces of tourism encounters and indicate shift toward (previously) mundane and "normal" settings (Gravari-Barbas and Fagnoni, 2013). Thus, ordinary in the sense used in this paper refers to the settings not traditionally associated with touristic offer and consumption.

As Urry (1995) suggests, contemporary tourism represents a fertile ground for the blurred boundary between tourism and non-tourism, particularly in terms of the new travelers' practices. Furthermore, it becomes even more obvious when observed in relation to the specificities of a "destination." According to Young, if we ascribe a particular value and/or meaning to a certain place, it will gain a sort of attractiveness and potentially transform from the ordinary into the tourist place, fact that confirms the vivid dynamic and fluidness of tourism (Young, 1999). These ordinary places are the ones where contemporary tourists are searching for the (perceived) authenticity, while trying to stay "off-the-beaten-track."

The invitation to break out from the established practices and experiences of "mass" tourism come from various directions, as suggested by Gravari-Barbas and Delaplace (2015), while naming alternative actors (NGOs, inhabitants, etc.) in tourism as important as the classical ones, for shaping the contemporary tourism trajectories. The case study presented in this paper supports this assumption and offers an insight into a complex web of individuals, organizations, tourists and tourism market involved in tourists' visits to New Belgrade.

Although Belgrade[1] is passing through the rapid development of tourism in the last decade, it is far away from the saturation in the sense of tourists' visits, as some other European cities are. Nevertheless, the number and diversity of visited locations is inevitably enlarged, some of them including "ordinary" objects and sites. The intention of this paper is to analyze the practices of the tourism of the ordinary by introspecting the specific case of New Belgrade (Novi Beograd in Serbian), the most populated municipality of Belgrade and Serbia (212.000 inhabitants; Figure 1).

The reasons for choosing New Belgrade are mostly gathered around the fact that this municipality has been passing through the most visible and significant transformation from its construction to the present day. Although this transformation mostly refers to the urban and functional characteristics, it increased locals' and visitors' interests about its cultural and touristic value as well. The complexities that will arise here are mainly sourced in multifaceted and heterogeneous characteristics of the very New Belgrade and its genesis. Oftentimes New Belgrade is portrayed as clear-cut project initiated by the dominant ideology of a socialist state, on an empty piece of land opposite to the old part of the city. The actual state of affairs could not be further away from this, as many authors have successfully been pointing out (Kulić, 2012, 2013, 2014; Blagojević, 2007; Le Normand, 2014; Waley, 2011). It consisted of paradoxal shifts, rough changes and above all represents a "complex urban collage," as Kulić (2014) described the turbulent history of New Belgrade.

Another particular reason for choosing to shed light to New Belgrade is the fact that its position within the scope of Belgrade's tourism is rather peripheral, despite its size, location and urban significance. The overwhelming majority of tourism sites, activities, pop-up events, walking tours, pedestrian zones and other points of interest are located in the old, historical core of the city. Such a distribution is commanded, not only by physical and morphological characteristics of the city, but by the activities of various tourism stakeholders too, from tour-guides (Rabotić, 2010) to official tourism bodies. One of the most significant contributions to such concentration is 


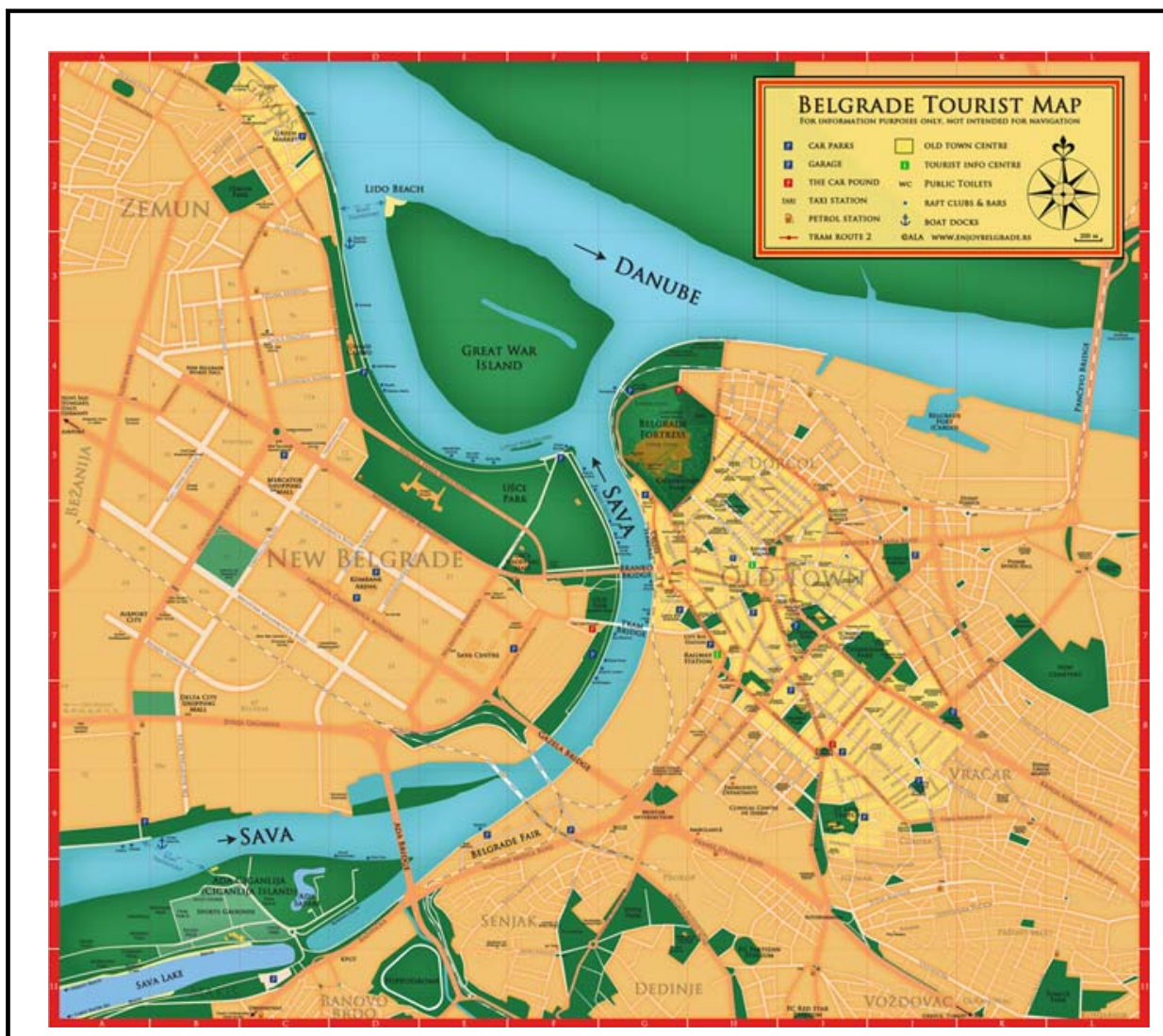

Source: Beligrad.com 2018

recognized in the activities of Tourist Organization of Belgrade (TOB), city of Belgrade's public agency for presentation, development and promotion of tourist values (tob.rs). Most of the recommended sites and experiences within Belgrade are located in the historical core.

Such a distribution tends to saturate certain parts of town with touristic attractions and lock certain areas to expected practices of tourism, while leaving others aside. Apart from overburdening some areas with consequences of tourism industries (Gant, 2016; Gotham, 2005), it makes other areas open and available for different kind of tourism consumption, with alternative patterns of tourism participation. The position of Old Belgrade as core of attraction-based tourism makes New Belgrade an area left-out from mainstream tourism attention, making it potentially suitable for all those practices associated with the "tourism of the ordinary." The position of periphery, together with various landmarks and opportunities for unique experiences recommend New Belgrade to "tourists of the ordinary" who are, in very limited number though, beginning to explore its allure. Conditions leading to such explorations are further analyzed in this paper and for making the arguments more illustrative, it is the authors' stance that an introduction of New Belgrade as urban, political, economic and cultural center is necessary.

Inseparably tangled with the built environment, tourism offer and consumption heavily rely on the ways such environment is valorized and communicated between both locals and tourists and tourists themselves. New Belgrade, as distinctively modernist "city" in terms of both architecture and urban disposition, yet awaits proper valorization, from "local" and "outside" perspective, possibly in the long queue of cities and urban sections knocking on the door of an emerging trend of recognition of the twentieth century architecture. Multiple sources linking modernist cities, its architectural/ urban legacies with tourism indicate completely opposing stances - from now - famous Skopje 2014 project that annihilates existing urban characteristics (Graan, 2013; Ivkovska, 2014) to Unesco 
international recognition in the case of Le Havre in France (Gravari-Barbas and Renard, 2010). In both cases, tourists' perspective, their interest and admiration mirrored in visits and landscape "consumption" is rather important element of local appreciation of the built environment. It is the effect of the Gaze (Urry and Larsen, 2011) that sets the tone for the local appreciation[2], both bottom-up and top-down. New Belgrade is somewhat comparable to the mentioned cases and its similarities and differences will be further considered in the light of the "tourism of the ordinary."

As far as specific approach is concerned, some archival and librarian materials have been analyzed in order to map the territory that is being researched (New Belgrade) and to frame the significance of potential heritagisation (Harrison, 2013) on the built environment and its territory. Further, relevant websites and both primary and secondary resources have been consulted. This mostly refers to the websites of TOB and the Institute for the Protection of Cultural Monuments in Belgrade as two most relevant bodies connecting the urban fabric of the city and its tourism valorization.

\section{New Belgrade - from the swamp, through federal dormitory to the post-socialist business center}

The end of the Second World War in Europe left many urban areas devastated, their infrastructure in ruins and housing stock severely reduced. Belgrade was no exception and its urban fabric, as well as inhabitants, suffered a great deal of misfortunes during the four years of War. Great number of residential buildings, family homes and other forms of housing was left in ruins - almost 50 percent of its residential structures - 12,889 out of 30,000-were partly or completely destroyed (Somborski, 1951, p. 51).

At the same time, Belgrade and Yugoslavia were going through complex shift in ideological and governmental changes - Monarchy was abolished, King forbidden from returning from his UK exile, new Constitution was enacted that set the path for decades long rule of the Yugoslav Communist party with its charismatic leader Josip Broz Tito at the helm. In such a turbulent times, the idea of moving the city from its pre-war perimeters toward the swampy plains of Danube and Sava confluence was conceived and the project was given high priority. It was decided that the left bank of Sava river is to become new center of Belgrade, capital of new socialist Yugoslavia (Plate 1).

Early post-war attempts to envisage a new city univocally showcase strong links between Tito's administration with Stalin's SSSR. New Belgrade thus came to embody both the transfer of ideology, culture and social organization from the Soviet Union to Yugoslavia and the attempt at reorienting the social imaginary toward Moscow as the center to which the country gravitated, claims Kulić (2013, p. 42).

Constructing New Belgrade ex nihilo was not simply an attempt to widen the existing city and prepare it to be a functional capital of a country that will number $20 \mathrm{~m}$ inhabitants in the future, but an activity in which the core fabric of new society was woven. The intention was clear - to institutionalize an immense bureaucratic machine of a centralist state and represent such position with a series of monumental structures, ranging from party headquarters, federal government building to various ministries and other bodies characteristic to a pro-soviet regime. The role of New Belgrade in early post-war years was multifocal - functional and symbolic. To host new government structures, to sever the links with pre-war capitalist city across the river and showcase the power of the state through a series of buildings that were to produce an awe effect. In socialist and communist systems, (public) space was a prerogative of the people, not the capital and hence must inherently carry ideological connotations (cf. Le Normand, 2014).

The beginning of 1950s carried many important directives made by the communists. One of the most significant moves was the 1950s decision to shift focus from industrial to consumption economy. In terms of New Belgrade, this meant complete shift in vision. Newly proclaimed decentralization crushed the plans for grandiose administrative center of a centralized country and the rise of the standard meant that New Belgrade will be the place where one of the most pressing issues of modern socialist Yugoslavia was to be addressed - the issue of housing.

In this phase of the New Belgrade's development, the second phase, the idea of building a representative capital with the power of the state as its pillar became quickly substituted with 


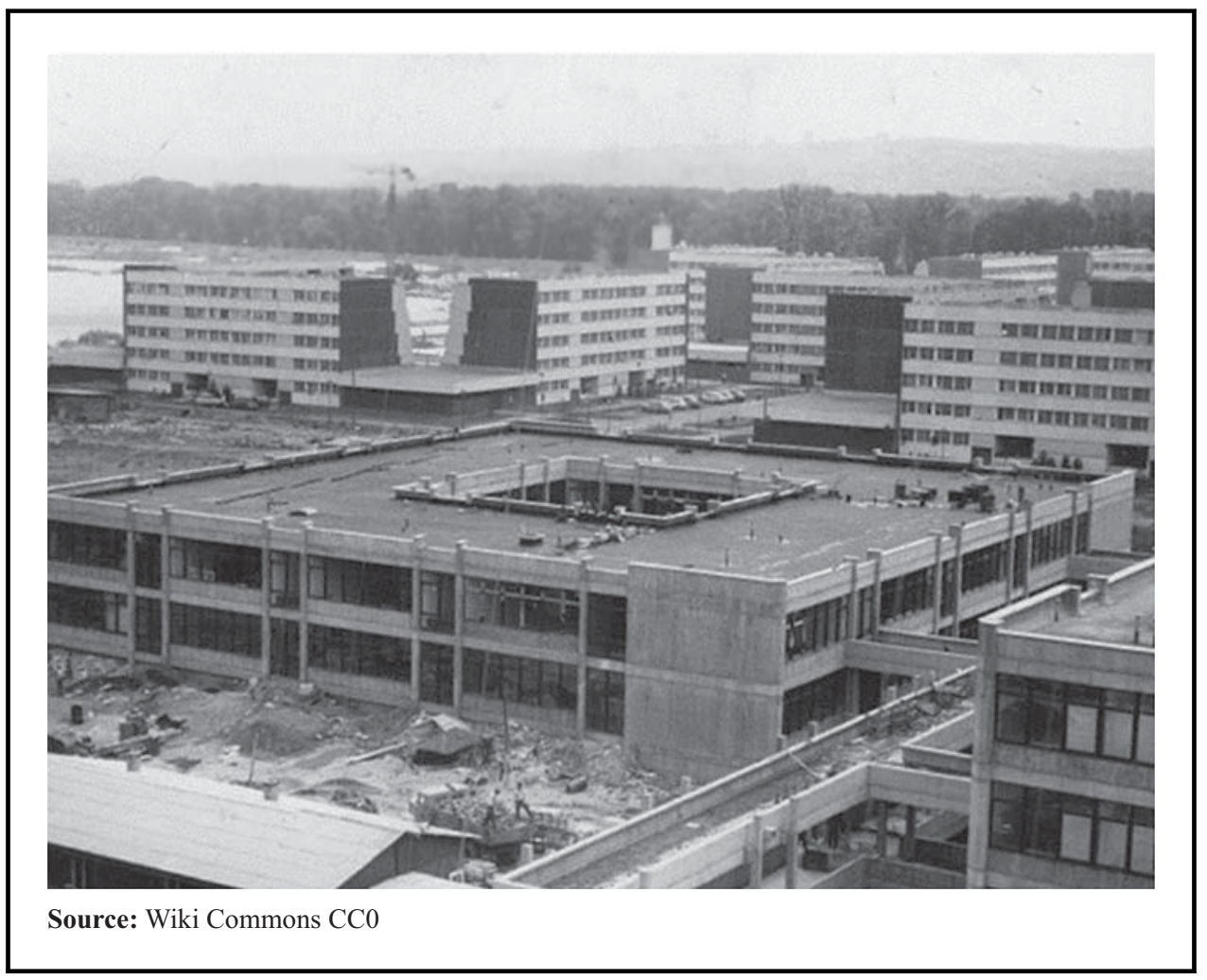

another kind of representation - one in which a socialist individual is affirmed and his/her needs are catered for. The needs of an individual, with its rising standard of living, begin from the housing issue, and that is where the new image of Yugoslavia should be situated. With this the role of New Belgrade moved from symbolism of political power toward the symbolism of housing, in other words from the space of sacred to the space of profane[3].

Thus, the role of housing became one of the predominant functions of New Belgrade, so dominating that it took priority from many other functions of a city, namely, transportation, social, cultural and other. Buildings were constructed to carry as many apartments as possible, with little attention paid to complementary facilities/services needed for proclaimed rise of the living standard. Missing hair-salons, bakeries, libraries and reading rooms were common sight, while at the same time, the number of apartments rose annually. "New Belgrade during this period could be better described as an isolated and underequipped dormitory settlement than as the new center of a socialist capital city" reminds Le Normand (2014, p. 81), describing the pattern of inhabitants behavior in relation to hotels and guests - "They lived in New Belgrade as if in a hotel, only staying there to eat and sleep" (Le Normand, 2014, p. 198) (Plate 2).

At the same time, during the 1960s, Yugoslavia endorsed market socialism, fact that further deepened the urban problems of New Belgrade and the idea of egalitarian approach to housing. This in real life meant that now apartments are not only provided free of charge for the workers, but could be bought - fact that many construction companies explored by building luxury apartments. In a very complex system of loans, company-owned apartments and clientelistic practices, better apartments were allocated to white collar workers, while those from the lower social strata were oftentimes neglected, as depicted by Archer et al. (2016).

It would be wrong to assume that New Belgrade contained nothing but residential buildings - Federal Executive Council building, a short walk from the Tower of Central Committee, together with other buildings of political and cultural significance were placed there. Most notably, the building of Museum of Contemporary Art, one of the most active cultural institutions of socialist Belgrade. 


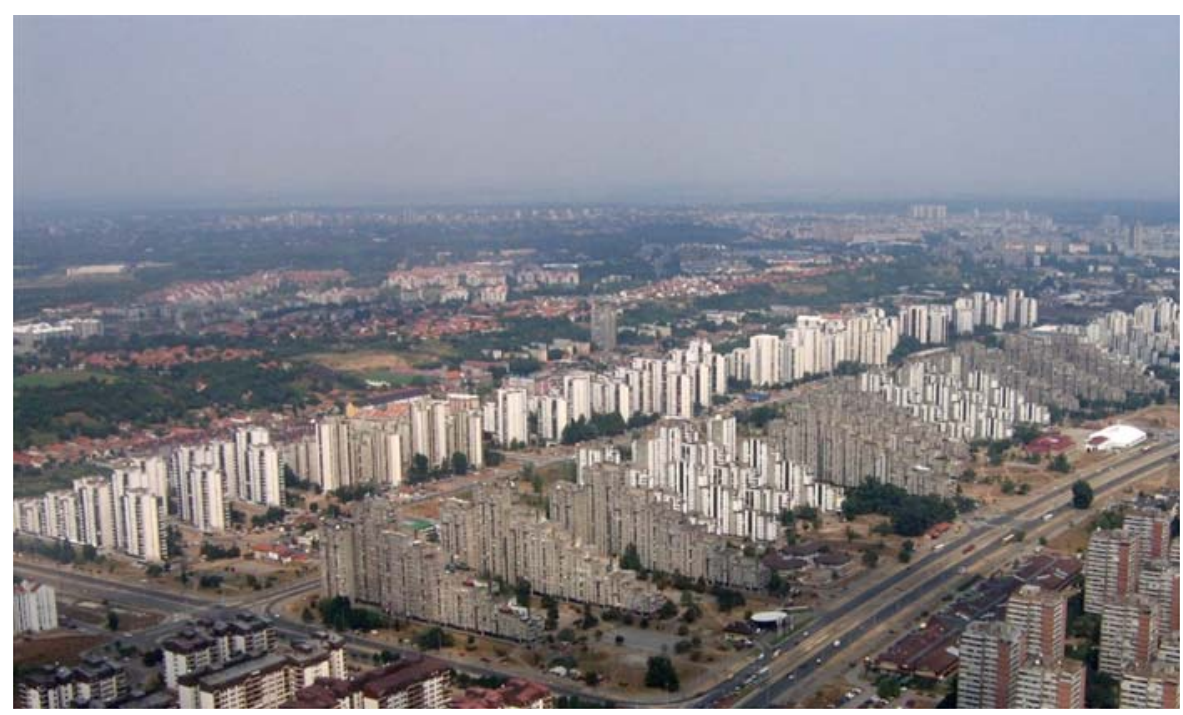

Source: Wiki Commons Public Domain; author: Rela; May 30, 2009

Nevertheless, these structures were oftentimes described as out of context or non-engageable (cf. Le Normand, 2014). One cannot enter government structures or business towers (such as world famous Genex tower) if one does not work there. Otherwise, these structures are simply reference points on a landscape of a transient citizen.

During the late stage of Yugoslav socialism, namely 1980s, New Belgrade was seen as a symbol of failed promises and misleading ideals. Even much so, in his study of New Belgrade, famous Henri Lefebvre vocally expressed his opinion about the matter, with an explosive opening statement of his joint work with Serge Renaudie and Pierre Guilbard:

The plannification of Novi Beograd has failed, both in its attempt at global coherence and in its political will to create a city. The conceptual and morphological shematism of the zoning and grid could lead only to failure, social and urban. What remains of the desire for ordered functionalism and summary purism [...] towers and bars of ominous dimension, lost in a deserted space where neither the public nor the intimate find their place. [...] The bars and towers, progressively abandoned, would become the ruins of another time, a museum in a memory of a former era where individuals were not entitled to be citizens in full measure. (quoted in Bitter and Weber, 2009, pp. 4-5)

Little did he know at that moment in 1986 that New Belgrade will indeed one day be observed by architectural historians and theoreticians as a kind of a museum, not only to a space failed to be articulated, but to an idea failed to be realized (Blagojević, 2007; Le Normand, 2014; Kulić, 2013, 2014; Perović, 2008) (Plate 3).

Simultaneously with the breakup of Yugoslavia, New Belgrade was going astray from everything it was intended to be - both as a representative of a state that is no more and the location of egalitarian housing opportunities for workers of all profiles. As brilliantly described by Kulić (2014, p. 58), New Belgrade was becoming its opposite:

It is hard to imagine a more emphatic denial of a city's symbolic meanings than what happened in New Belgrade during the 1990s. The city of rational socialist planning became a city of small-scale gray economy. Instead of foreign dignitaries planting trees, nationalist rallies engulfed the confluence of the Danube and the Sava. Instead of motorcades with Tito and his non-aligned guests, masses greeted the tanks and armored vehicles crawling down the Highway of Brotherhood and Unity to secessionist Croatia. American Tomahawks bombed the tower of the Central Committee, demolishing its

"American facade[4]" with the whole world watching. 


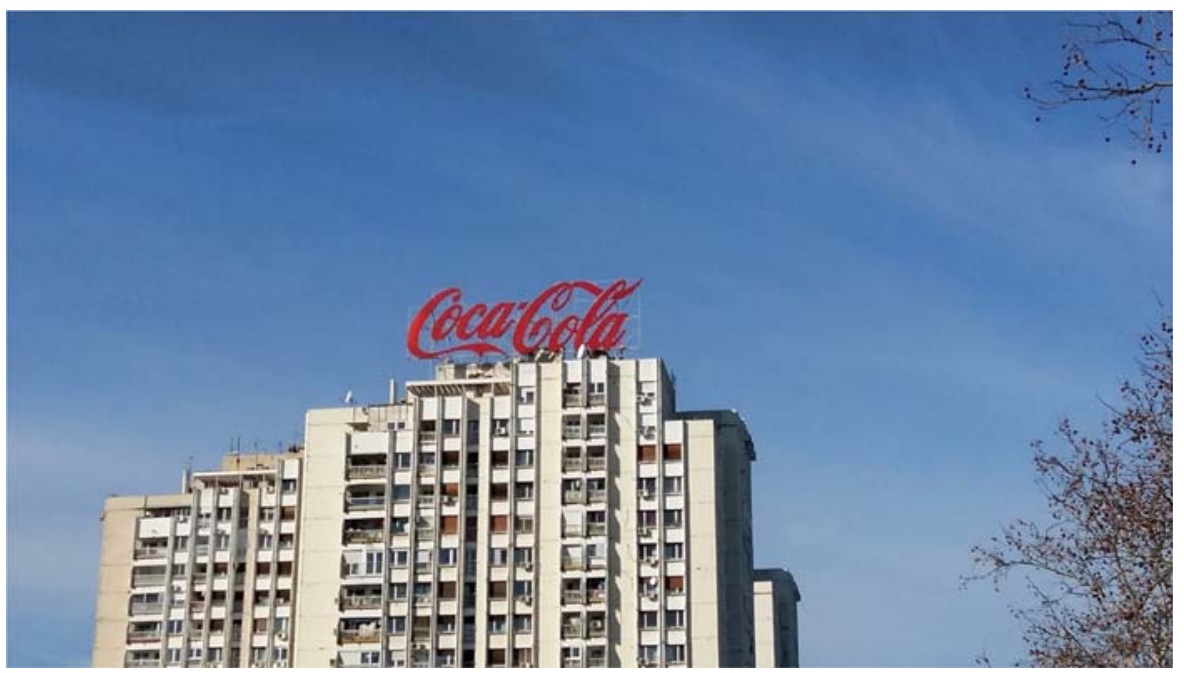

Source: Authors, December 13, 2017

As such - unfinished, fragmented, complex urban collage of New Belgrade became ideal playground during the turbulent years of post-socialism in Serbia. Nowadays, it hosts multinational companies from the world of finance, IT, heavy industries, etc. Paradoxically, once socialist-envisioned city became the heart of neo-liberal Serbia in which people witnessed large developments of commercial and cultural complexes that began satisfying the needs of the locals, but these fillings among the gaps of socialist-time plans created many ruptures that left space for reinterpretations, reinventions and resemantization. Nowadays, New Belgrade is Serbia's largest municipality, population-wise, as well as its business core.

\section{New Belgrade and tourism of the ordinary}

Alongside with the uneven development of the area in the socialist times, with the housing function being predominant, the tourist side was neglected too. In a quick glance over several Belgrade promotional videos, from both the socialist-Yugoslav and contemporary Serbian era[5], one can observe the old city from multiple perspectives, with different sides of tourism consumption practices being put forward - landscape images, casual strolling, shopping, heritage sites visits, etc., while only a few sequences are dedicated to New Belgrade, and them mostly being aerial photos. This fact, present in today's relationship between the old and the new Belgrade is a fact worth exploring.

Although Belgrade is experiencing steady rise in numbers regarding tourist arrivals, length of stay and on-site expenditure[6], New Belgrade is nowhere to be seen on the map of tourism offer, as per Belgrade's Tourism Organization. TOB's official web page (www.tob.rs), at the time this piece is written, in the section "Attractions," mentions nothing regarding New Belgrade. Among 13 entries - 12 are historic sites of more than a century behind them and one is a lake and outdoor destination. Leaving aside the narrative that TOB is weaving with such a selection, it is inevitable to notice the discrepancy among the officially recommended sites and visitable locations, as New Belgrade confirms. After all, one of the iconic photographs of Belgrade is actually New Belgrade panorama/vista, seen from the terraces of Belgrade fortress (Plate 4).

According to many of Belgrade's formal and semi-formal actors in tourism - including tour agents, incoming agencies, independent tour-guides - New Belgrade is slowly being explored by specific segment of tourists those seeking informal, everyday and ordinary settings, mainly as a wish to acquire genius loci with a bottom-up approach[7]. Although a proper survey of 


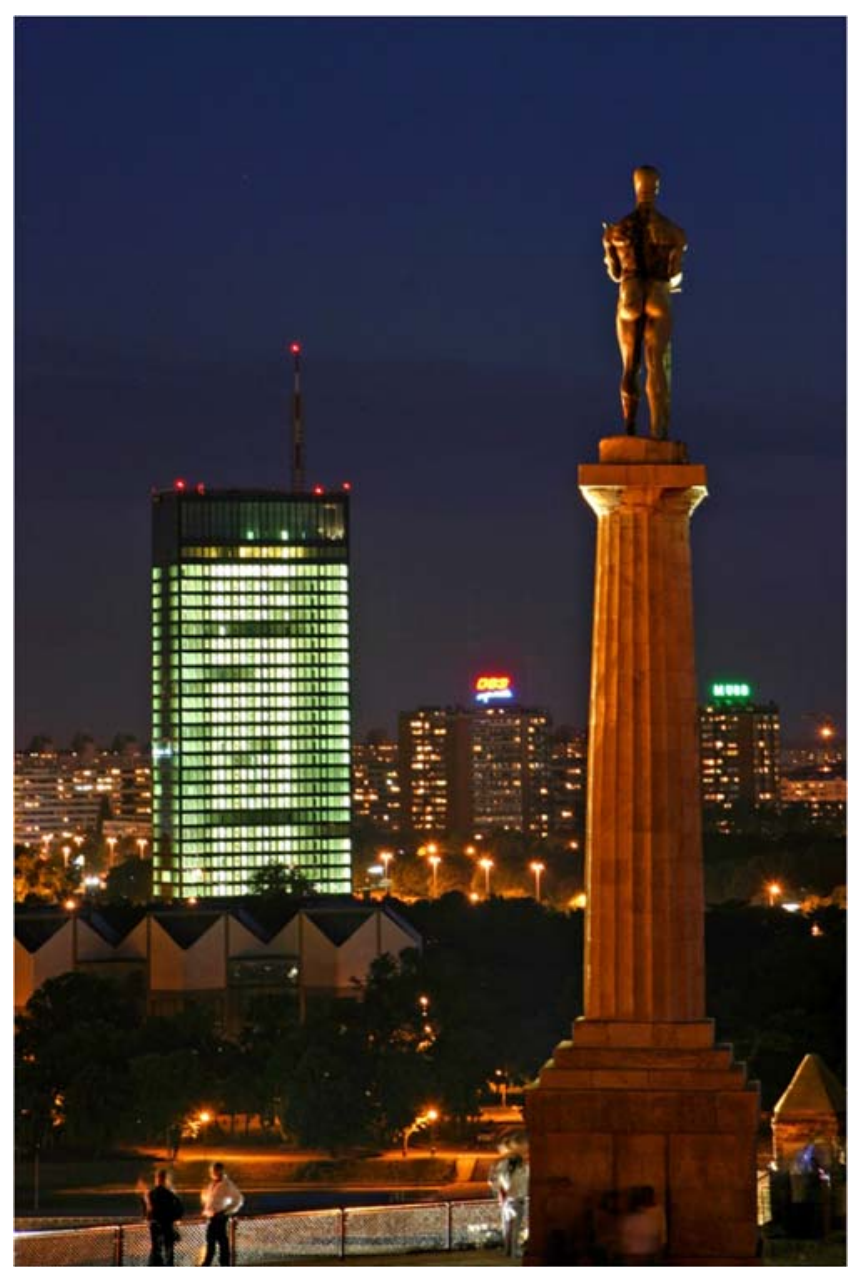

Source: Wiki Commons; author: Masasrb; September 1, 2013

such tourists is yet to be completed, initial information indicates that lifestyle, nightlife and lived urban experience are among the main reasons leading to the visits to New Belgrade. Getting away from the routine and excitement and contact with the local residents have been recognized as the main push and pull factors in young tourists' motivation to visit Belgrade (Todorović and Jovičić, 2016).

At this point, it is necessary to offer potential distinction between urban location as landmark and as attraction, in which the main separating factor is the level of tourism attractiveness and consumption associated to it. Landmark could be characterized by intrinsically unique values/ characteristics presented in certain objects or spaces, such as location, volume, architectural style, etc., that separates it from surrounding objects and spaces or those comparable in function. Attraction is, on the other hand, always associated with tourism (Harris and Howard, 1996; Lew, 1987, 2014), while at the same time not possessing any physical ability to attract tourists by itself (Leiper, 1990), always relying to the mind and imagination of the tourist to draw its attractiveness from (Lew, 2014, p. 363). This is of particular importance for the case of New Belgrade, which is not lacking landmarks, both in build and natural environment, as will be indicated in the following examples of walks, tours and maps.

Understanding that there is more to Belgrade than the attractions of the old historical center and backed up by the emerging solo tourist explorers of New Belgrade, several independent tour 
agencies, cultural associations and individual professionals began offering walking or cycling tours around New Belgrade, with particular focus on "lifestyle of ordinary people" (belgradefreetour.com). Again, "outside eyes" as suggested by Urry and Larsen (2011) backed up such business initiatives - The Guardian named "New Belgrade bike tour" one of the ten best alternative city tours in Europe in 2016 (Coldwell, 2016) and Evening Standard even published a coverage of such a tour, suggesting several not-to-be-missed locations: Genex tower, Sava Centar, Hotel Jugoslavia and several residential blocks (Tierney, 2016). Beside walking tours, cycling groups, specialist rent-a-car agency (Yugoturs) offer explorations in Yugoslav made automobiles, thus creating a specific sensory experience[8] (Plate 5).

Moreover, Tačka komunikacije (point of communication) is a media agency and cultural association that prepares walking tour itinerary for both foreign and domestic tourists "Residential New Belgrade: From the brutalist bastion to the garden city" specially focused on the lived experience of the local residents. At the same time, still in Belgrade, another cultural organization, offers two different bike tours that include architecture and beach (riverbank) and special written guide to self-conducted walking tour around New Belgrade (Christine, 2014). Ljubica Slavković, an architect and curator of Belgrade Brutalist Map by Bluecrawmedia, spoke for Lonely Planet - "this map is an invitation to explore and recognise some of the most prominent achievements of Tito's Yugoslavia and Modernist architecture in existence today. Although Belgrade is home to an unsurpassed density of original Modernist and Brutalist architecture and design, the lack of public support and maintenance means that many of these structures are now in danger. We want to draw the public's attention to these achievements before it is too late" McCarthy (2017) (Figure 2).

Plate 5 Retro car tours by Yugotour around New Belgrade

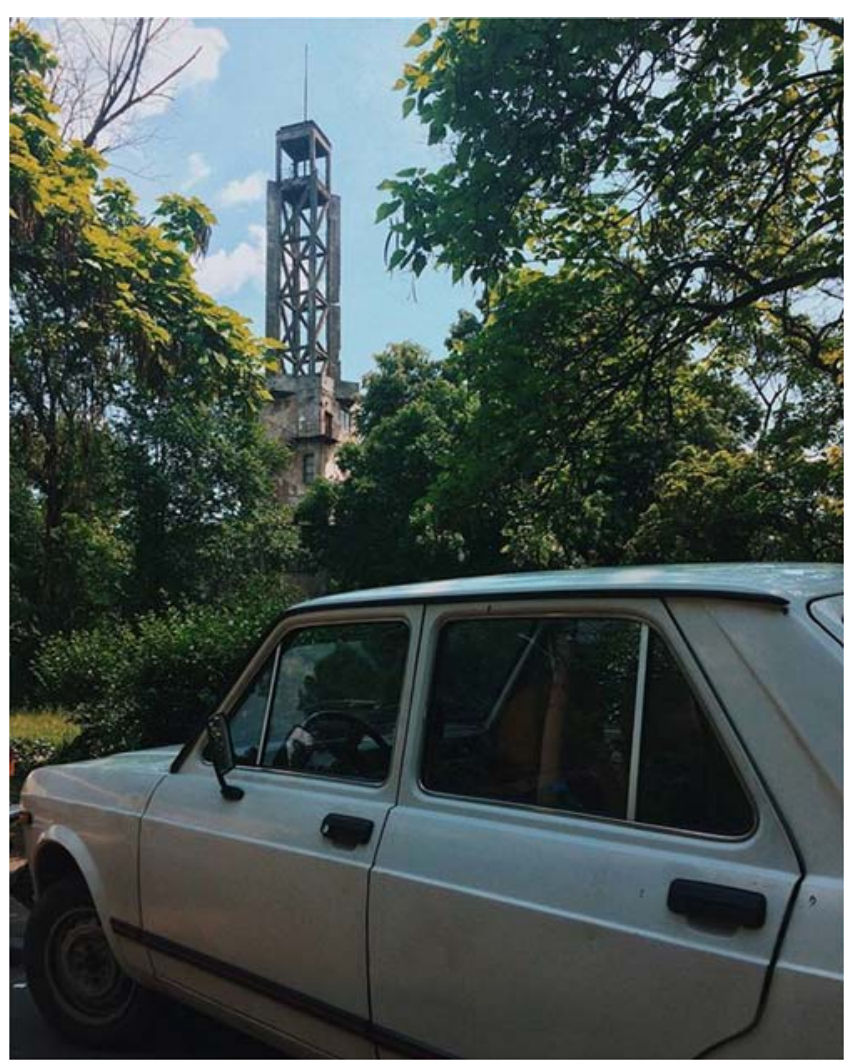

Source: Instagram yugotour_bg; May 30, 2017 


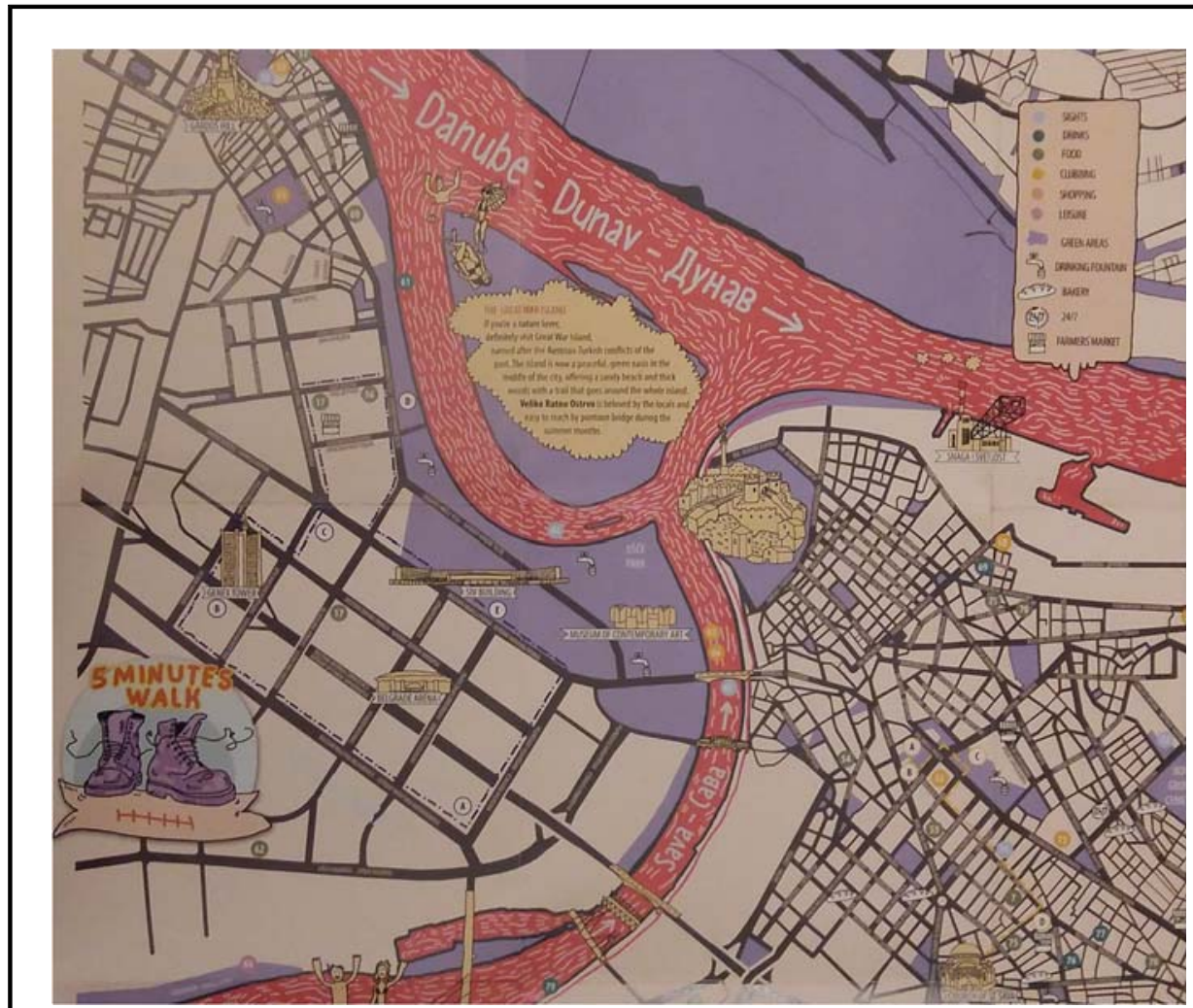

Source: Authors, October 7, 2017

Walking, cycling and retro-automobile tours are suggested or organized to take tourists in areas beyond the city that is commodified for tourism consumption, beyond the mapped set of attractions offered predominantly in the old core of the city. Specific thematic tours are offered by architectural professional organizations (namely 360Belgrade), aiming to showcase the city developments happening in recent history and underline its qualities as one of finest brutalism developments in Europe. However, all of the organized efforts to present New Belgrade to tourists meet the same difficulty - there is no singular set of "attractions" or must-see destinations within New Belgrade. Hence, every tourist group venture to New Belgrade is an exploratory enterprise, a survey of the ordinary and common. The lack of set objects, processes or people (in another word-attractions) that are prefabricated and commodified for tourism consumption aligns New Belgrade with the tourism of the ordinary.

The ordinary of New Belgrade, in touristic framework, is perceived in relation to attractiveness (or in the abundance of attractions) of the old part of the city. Recalling Tuan's (1977) notion that both "space" and "place" require each other for definition, we would suggest that attractions and "the ordinary" stand in similar dispositions. They are defined in terms of relatedness via social actions. By labeling something as attraction, its binary counterpart is gaining the aura of ordinary, no matter how mundane or unique it might be (as we will see later, again in the case of New Belgrade). For Belgrade, attractions and dominant tourism narrative gather locations, experiences and actors that revolve around the Second pre-World War contents. Links to Belgrade's pre-communist life are put forward, simultaneously shadowing the legacies of communism, where New Belgrade stands in the center[9]. Such practice should also be read in the context of post-socialist transformation of Serbia, where legacies toward the communist rule of Serbia are still debated and articulated (cf. Simić, 2014; Jansen, 2005). 
With that in mind, the "shadowed" landscape of New Belgrade is seen as ordinary and worthy a visit for those whose patterns of consumption in tourism put forward the characteristics of what we now call "ordinary" (Lefebvre, 1947; Williams, 1958) - be it the escape from the locations plagued by mass tourism and high number of visitors or culturalist practices that oppose the narrative of attraction.[10] Exactly at this point, it is important to put forward the complex structure of New Belgrade in which its tourism boundaries are defined not by its inherent qualities, but by practices of those who visit it. Being on the margins of tourism consumption of Belgrade, the New Belgrade relies on the visitors to shed light to it and the light being shed is the one of the ordinary.

Another understanding of New Belgrade as the ordinary and not niche tourism is the lack of the product/service itself that is catering the niche market. The absence of established actors, tourism infrastructure, almost non-existent promotion and very limited number of visitors speak only of a potential for creation of the niche or micro-niche market (modernist/brutalist aficionados among the architecture tourists). As Robinson (Novelli, 2005) suggests, niche tourism revolves around matching particular tourism imaginaries and market systems capable of catering to them - "Niche tourism is an economy of imagination, where individual preferences and practices are coordinated, packaged and sold. The wants and wishes of the bird watcher, the golfer, the genealogist, the railway enthusiast, can now be purchased; indeed, the fullest stretches of the imagination can now be catered for." The link connecting the niche demand and the supply is established market, something New Belgrade is lacking. However, niche tourists are seen to have the same goal as those engaged in "ordinary" tourism - distancing themselves from what the "mass" tourism is and aligning themselves with the "cosmopolitism" (Hannerz, 1996; Seaton, 2002), so this thin distinction is certainly in need of further analysis.

New Belgrade lacks no physical qualities, nor is in other way considered as location to be avoided by tourists (on the matters of safety, difficulties of getting there, etc.). Its promenades by the river easily surpass those located in the old core of Belgrade in terms of available amenities, water-taxis (non-existent in the old core), potentials for accessing islets of Belgrade, etc. One of the largest sculpture parks with soon-to-be refurbished and reopened Museum of Contemporary Art is located there. Finally, the buildings constructed during the time of Socialist Yugoslavia are considered to be finest examples of high-modern and brutalist style in Europe. According to the Institute for the Protection of Cultural Monuments in Belgrade, various sites and structures around New Belgrade enjoy status of state or city protection, highlighting their significance and value. Among other are Genex residential and business tower (Plate 6), Museum of Contemporary Art (Plate 7), Federal Executive Council Building (Plate 8) and various other ambient units and buildings that have been enlisted. However, their de juro protection is not reflected in any de facto care - Genex is dilapidating and mentioned museum has been closed for ten years due to bad structural conditions of the building[11]. Moreover, none of these protected sites and structures, as well as many other significant but not enlisted units are included in tourism offer of Belgrade, as per Tourism Organizations of Belgrade and Serbia.

Such a position, in which official state bodies are weaving opposing narratives, in which something that enjoys protection by the law is not in any way placed among visit-worthy attractions, leaves New Belgrade in a peculiar position. Being centrally located, yet not-communicated toward tourism markets; adorned with landmarks, but not attractions, New Belgrade is particularly suitable for engaging in the tourism activities of the "ordinary." Taking in mind the Lew's (summary in Williams and Lew, 2014, p. 223) division of space in tourism (terra cognita, terra incognita and terra intimidus), we would place New Belgrade among the terra incognita subcategory. Incognita is associated with individual and unique experiences, often unexpected and carrying certain level of risk, but also exotic, challenging and authentic[12]. Tourism consumption in such spaces are indeed happening in an extended framework of global tourism, it is structured in tourism economy and is relying to some kind of guiding practices - be it through hired local guides or self-guided activities assisted with printed/digital data. This indeed reflects the practices of the New Belgrade tourists' visits, in which specialized guides take interested parties through New Belgrade, or in which travelers 


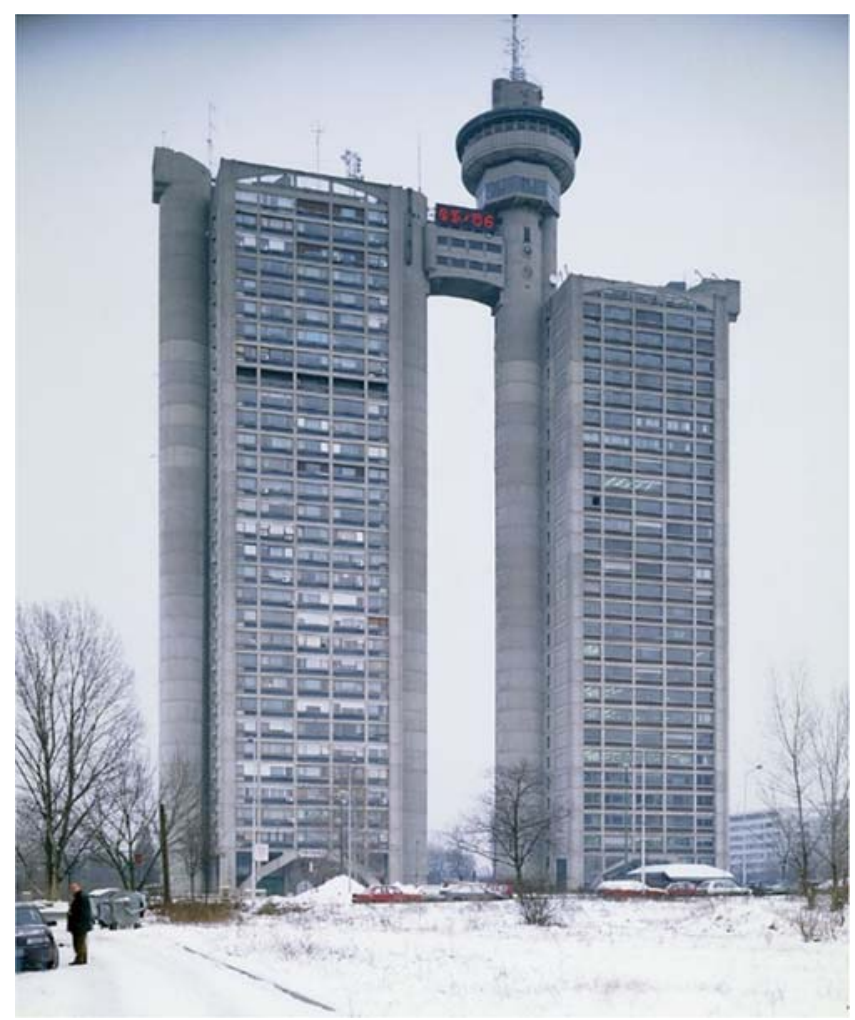

Source: Wiki Commons CC BY-SA 3.0; author: Błażej Pindor; December 1, 2003

themselves explore various areas of interest helped by visual or textual sources, often coming from sources other than tourism publications (Plate 9).

Such positioning practices, earlier mentioned, should be understood in the framework developed by Michel de Certeau (1980), in the framework of strategy/tactics, in which tactics are not seen as subordinate to strategy but as directly opposed to it. Such a concept aligns strategy with the position of power, as ways of asserting the preferred meaning, while the tactics work in direct opposition to the strategy, as a democratic response. In this case, we mainly refer to the power of state apparatuses, congregated around tourism bodies, agencies, decision-making individuals; to the nexus between tourism industry and metropolitan/municipal authority.

In the sense of tourist practices of Belgrade, we would argue that attractions, as previously mentioned, work as strategy in de Certeauian terms, and place Old Belgrade at the center of travelers' attention, while leaving New Belgrade aside. In other words, New Belgrade's absence of attractions is clear only when observed in the relation to the Old Belgrade, the same as the practices of tourism consumption of New Belgrade stand in relation as tactics to the proclaimed attractions of the old core. Tourism practices of the ordinary thus position the place in the contrast to the attraction, regardless of the inherent properties of such a space.

Such a position is poignantly illustrated in the case of Yugodom - "Unique mid-century modern design guesthouse in Belgrade, Serbia. Accommodation that recreates an authentic Yugoslav home in a form of a museum" (yugodom.com). Although entirely dedicated to the Yugoslav industrial design and interior architecture, aiming to showcase everyday life in average Yugoslav household, Yugodom is located in the center of the old core of the city, miles away from New Belgrade. This private museum - guesthouse draws parallel with the Perret 


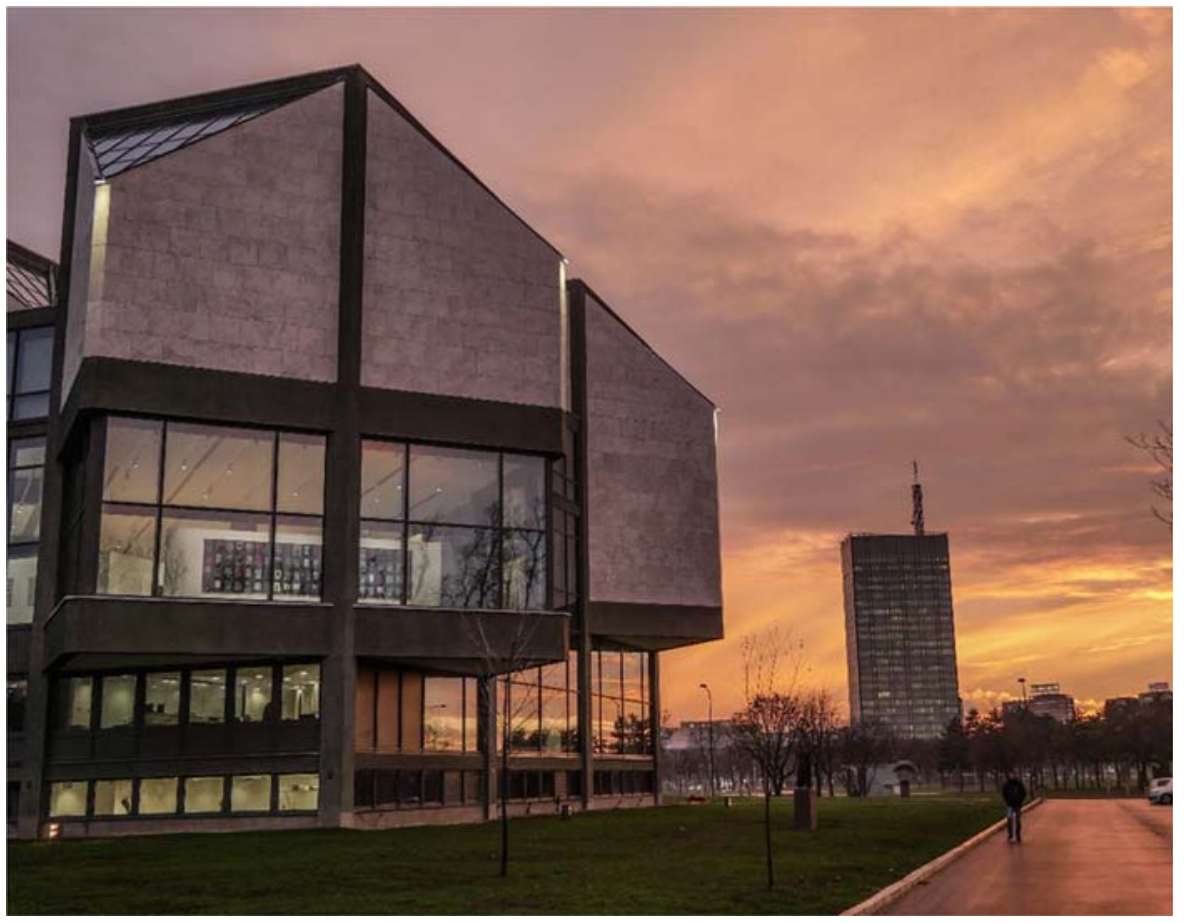

Source: Courtesy of the author Srdjan Garcevic; November 30, 2017

Plate 8 Palata Srbija, former Federal Executive Council Building

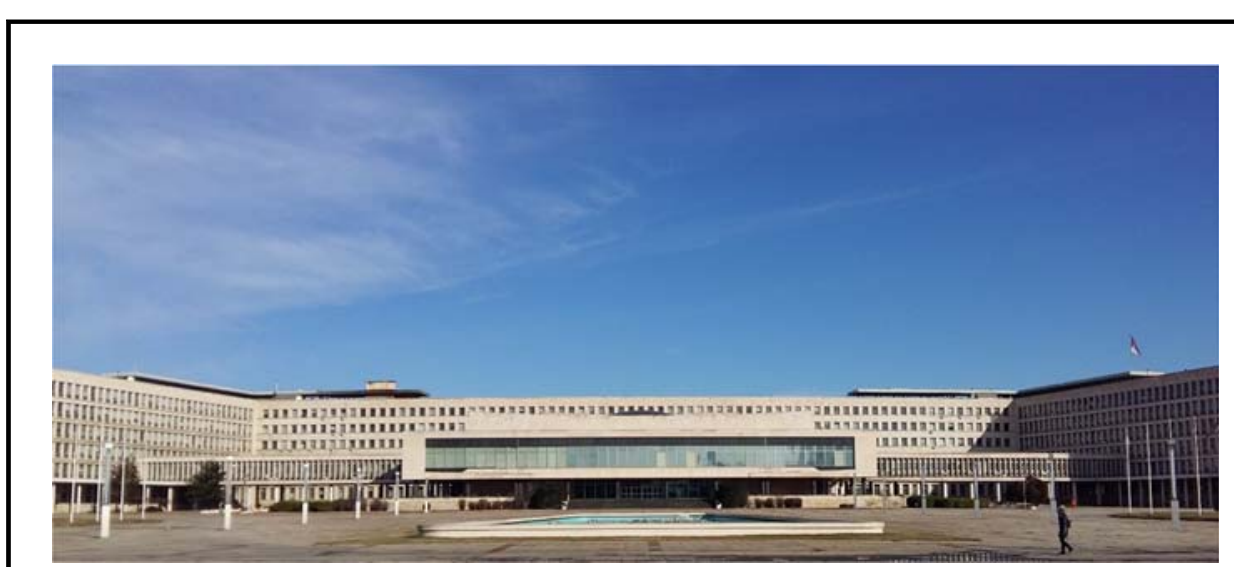

Source: Authors, December 13, 2017

apartment in Le Havre, which is also seen as a micro-museum designed primarily from local and authentic furniture elements, with the main purpose of bringing closer the experience of living in the Reconstructed city (Gravari-Barbas and Renard, 2010). Both venues are somewhat depersonalized, as none of them refer to the actual family or individual that lived there and that could adorn these spaces with personalized narratives. It is rather ideal representation of imagined dwelling, but in the city of Le Havre, it is situated among its architectural and 


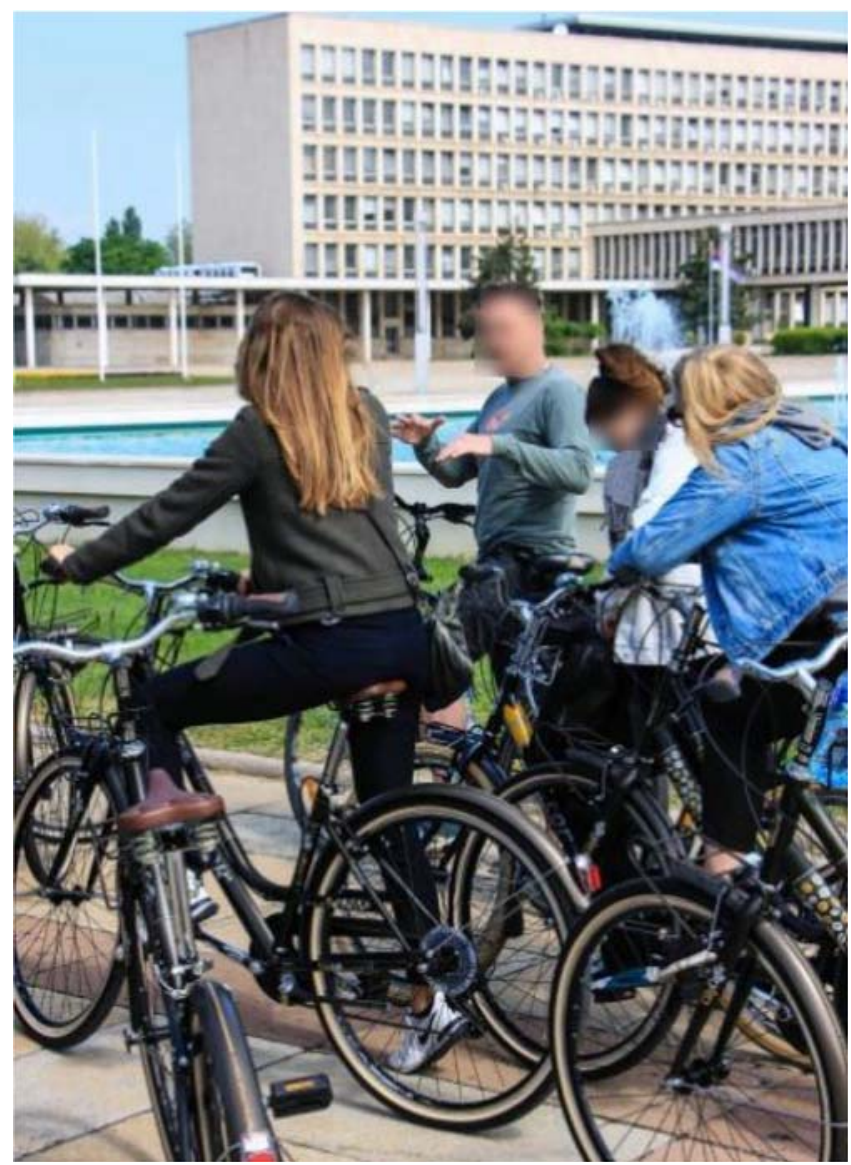

Source: belgradebikecentral.com

urban fabric. In Belgrade, once one walks out from Yugodom, one is in the middle of a stately street dotted with pre-war luxurious townhouses. With such characteristics, it is even more difficult to humanize the heritage and reconcile it with both urban and social context.

Further parallels between Belgrade and Le Havre in France could be made, especially in the fact that outside attention prompted local actors to engage in conceptualization and valorization of the respected sites (Gravari-Barbas and Renard, 2010). Contrary to the case of Le Havre, in Belgrade such outside attention produced bottom-up initiatives and attempts to bring forward local architectural heritage, as briefly described in the activities of various local cultural associations and active individuals. However, such initiatives are not rooted among the New Belgradians themselves, but rather among specific professionals - architects and cultural managers. This might echo the notion of powerful expert put forward by Smith (2006) when explaining who are the principal stakeholders in heritage making process, in her Authorized Heritage Discourse theory. However, experts without the support of influential institutions can do only so much. Missing rootedness primarily in local initiatives and lack of the support from the top, make these heritagisation attempts particularly fragile. The lack of progressive patrimonialization, as observed in Le Havre, did not lead to the development of tourist products in New Belgrade that would, in return, possibly sparkle the local interest and potential consequent appropriation among the locals[13].

Another detail that significantly reduces instant and easy valorization and branding of New Belgrade, both among foreign public and local citizens, is the fact that New Belgrade was not a 
masterpiece of single renowned architect - demiurge, whose life work is mirrored in its architecture and urban patterns. Unlike Niemeyer's Brasilia, Le Corbusier's Chandigarh or Perret's Le Havre, New Belgrade came out to be a joint and oftentimes conflicting visions of various professionals. Moreover, UNESCO label came as significant contribution to the residents of Le Havre in process of reconsidering their urban environment, as explained in "before" and "after" the World Heritage Listing status. New Belgrade lacks similar seminal moment or tangible recognition that would set the pace for local, both top-down and bottom-up reconsiderations. Such position, stemming from the described characteristics, makes New Belgrade particularly eligible for the engagement in the tourism of the ordinary.

With the understanding of attractions as something constructed, rather than inherent, it is clear that forces shaping such constructs might drive certain portions of tourists in the other direction. In search of everyday, lived, (imagined) authentic sights, people and activities, (rare) tourists visit New Belgrade and immerse themselves in the its multifocal past, appreciating that mentioned genius loci oftentimes comes in experiencing the contradictions and complexities of an urban palimpsest, rather than in following the secure path of attractions. By embracing a space with contested meanings like New Belgrade, by exploring new Belgrade and it is still tourism industry-intact environment, visitors are more likely to engage with the local community and its perceptions and lived experience of a location. This notion is sourced in fact that not a single section of urban infrastructure is made with tourism purposes in mind (unlike in the old core of Belgrade), and with almost non-existent tourism services and products available related to New Belgrade, visitors are directed much more toward the locals then they are in attractions-dotted part of town in which maps, street-signs, interactive direction poles and other tourist artefacts direct and inform their experience.

\section{Conclusion}

The complexities associated with New Belgrade since its early days, its heterogeneous character, shifting visions and consequentially sweeping differences in landscape, along with the fact that it was never a finished project, influenced its contemporary perceptions in the world of Belgrade's tourism. Not fitting exclusively into the category of residential nor business nor cultural, but not being far away from any of those, coupled with the fact that it bares whiteness to ambiguous stances toward the legacy of communism in Serbia made New Belgrade a location fit for opposing the world of attractions in the old core of the city, through the practices of the ordinary. In this paper, we have tried to demonstrate how tourism of the ordinary might be conducted in urban environment that lacks no tangible resources, whose physical physiognomies are not insignificant and which, in another, alternative tourism regime might be considered attractions. However, in the specific set of characteristics spanning from contested past to ambiguous contemporary valorization, New Belgrade remains an uncharted part of the city for much of the mainstream tourism, leaving its charms for very few visitors, most often engaged in interest of the "ordinary."

\section{Notes}

1. Belgrade is the capital of Serbia and home to $1.65 \mathrm{~m}$ inhabitants, while the whole country counts $7.18 \mathrm{~m}$ citizens. (source: www.srbija.gov.rs)

2. "Places are thus (re)produced through tourist performances that are made possible through networked relationships with other organizations, machines, and especially buildings" (Urry and Larsen, 2011). Further discussion on how local appreciation might follow tourists' appreciation is developed in chapter 8 "Places, buildings and design" of Urry and Larsen's (2011) book The Tourist Gaze 3.0 , with particular focus being paid to the concept of "mutual gaze," developed by Maoz (2006).

3. It is exactly in this fact that some authors source the layout and the present look of New Belgrade - cf. Blagojević (2007).

4. American facade refers directly to the public debate in which the aestetics of the Central Committee building was associated with the contemporary skyscrapers of Manhattan, in which capitalist companies maintained their HQs. Such a comparison played significant role in analyzing Yugoslavia's links to the West after its breakup with SSSR (Kulić, 2012). 
5. www.youtube.com/watch?v=_rWjOwPKZMA; www.youtube.com/watch?v=8qgJLMK9q4c

6. In 2017 total number of tourist arrivals in Belgrade was at $1.02 \mathrm{~m}$, which is 16 percent rise to 2016, with 19 percent rise in overnights at $2.17 \mathrm{~m}$ (source: Tourist Organisation of Belgrade).

7. At this point Loukaki (1997) raises important questions of "Whose genius loci?" bringing under the spotlight the ideas of contrasting interpretations and different readings of symbolic meanings in different sites. However important, this question stays out of the scope of this paper.

8. Utilizing legacies of communism in various spheres of touristic offer is common sight in many postsocialist countries. For details on local particularities (cf. Velikonja, 2009; Light, 2000; Rabotić 2012).

9. The exception to this are frequent tourists' visits to the mausoleum of Tito, who is seen as an exotic individual, and whose personal life is in the center of the tourist attention, not his legacy and impact on Belgrade and Serbia.

10. The authors are of the opinion that tourism practices associated with the "ordinary" character of New Belgrade, as described above, are foremost culturalist practices of self-positioning and micro-resistance, through which individuals critically engage with the world of contemporary tourism. However, since the study of such practices is currently underway, the findings will be published in a separate paper.

11. The lack of conservation is tightly linked with the larger context of ambiguous appreciation of modern built heritage from the communist era in various post-socialist countries. Serbia and Belgrade are no exception (Kadijević, 2008; Mecanov, 2010).

12. However neccessary, authors do not have presentable data that would show if the visitors to New Belgrade share such sentiments and experiences of the site. Data collection is underway, as mentioned previously.

13. The processes of valorization and conservation of modern and contemporary heritage is at the core of Modern Heritage Programme by UNESCO World Heritage Centre aimed at documentation and promotion of the built heritage of the nineteenth and twentieth centuries (cf. Ferguson et al. 2010; den Heuvel et al., 2008).

\section{References}

Andersson, T. (2007), "The tourist in the experience economy", Scandinavian Journal of Hospitality and Tourism, Vol. 7 No. 1, pp. 46-58.

Archer, R., Duda, I. and Stubbs, P. (2016), Social Inequalities and Discontent in Yugoslav Socialism, Routledge, London.

Bitter, S. and Weber, H. (2009), Autogestion, or Henri Lefebvre in New Belgrade, Fillip Editions and Stenberg Press, Vancouver.

Blagojević, L. (2007), Novi Beograd: Osporeni Modernizam, Zavod za udžbenike, Beograd.

Butler, R. (1990), "Alternative tourism: Pious Golden Hope Trojan Horse?", Journal of Travel Research, Vol. 28 No. 3, pp. 40-5.

Christine, C. (2014), "Guide to modern Yugoslav architecture", available at: http://stillinbelgrade.com/guidemodern-yugoslav-architecture/ (accessed December 5, 2017).

Coldwell, W. (2016), "10 of the best alternative city tours in Europe", available at: www.theguardian.com/travel/2016/aug/01/10-best-alternative-city-tours-europe-warsaw-reykjavikbarcelona (accessed December 5, 2017).

de Certeau, M. (1980), L'invention du quotidian, Folio, Paris.

den Heuvel, D., Mesman, M., Quist, W. and Lemmens, B. (2008), The Challenge of Change: Dealing with the Legacy of the Modern Movement, IOS Press, Amsterdam.

Ferguson, R., Harrison, R. and Weinbren, D. (2010), "Heritage and the recent and contemporary past", in Benton, T. (Ed.), Understanding Heritage and Memory, Manchester University Press, Manchester, pp. 277-315.

Gant, A.C. (2016), "Holiday rentals: the new gentrification battlefront", Sociological Research Online, Vol. 21 No. 3, pp. 1-9, available at: www.socresonline.org.uk/21/3/10.html (accessed on 5 December 2017). 
Gotham, K.F. (2005), "Tourism gentrification: the case of New Orleans' Vieux Carre (French Quarter)", Urban Studies, Vol. 42 No. 7, pp. 1099-121.

Graan, A. (2013), "Counterfeiting the nation? Skopje 2014 and the politics of nation branding in Macedonia", Cultural Anthropology, Vol. 28 No. 1, pp. 161-79.

Gravari-Barbas, M. and Delaplace, M. (2015), "Le tourisme urbain: hors des sentiers battus”, Téoros, Vol. 34 Nos 1-2, pp. 1-2.

Gravari-Barbas, M. and Fagnoni, E. (2013), Métropolisation et tourisme: Comment le tourisme redessine Paris, Belin, Paris.

Gravari-Barbas, M. and Jacquot, S. (2016), "No conflict? Discourses and management of tourism-related tensions in Paris", in Novy, J. and Columbus, C. (Eds), Resistance and Protest in the Tourist City, Coll. "Tourism and Mobility", Routledge/Taylor and Francis, London, pp. 31-52.

Gravari-Barbas, M. and Renard, C. (2010), "Une patrimonialisation sans appropriation? Le cas de l'architecture de la reconstruction au Havre”, Norois, Vol. 217 No. 4, pp. 57-73.

Guttentag, D. (2015), "Airbnb: disruptive innovation and the rise of an informal tourism accommodation sector", Current Issues in Tourism, Vol. 18 No. 12, pp. 1192-217.

Hall, C.M., Timothy, D.J. and Duvall, D.T. (2012), Safety and Security in Tourism: Relationships, Management, and Marketing, Routledge, New York, NY and London.

Hannerz, U. (1996), Transnational Connections - Culture, People, Places, Routledge, London.

Harris, R. and Howard, J. (1996), Dictionary of Travel \& Tourism Hospitality Terms, Hospitality Press, Melbourne.

Harrison, R. (2013), Heritage: Critical Approaches, Abingdon/Routledge, New York, NY/Milton Park.

Hoggart, R. (1957), The Uses of Literacy, Penguin books, London.

Ivkovska, V. (2014), "Re-inventing vernacular settlements for tourists: can the new Macedonian village represent true vernacular traditions?", ISVS e-journal, Vol. 3 No. 2, pp. 17-34.

Jansen, S. (2005), Antinacionalizam, XX Vek, Beograd.

Kadijević, A. (2008), "O socrealizmu u beogradskoj arhitekturi i njegovim oprečnim tumačenjima", Nasleđe, Vol. IX, pp. 75-88.

Kulić, V. (2012), "East? West? Or both? Foreign perceptions of architecture in socialist Yugoslavia", The Journal of Architecture, Vol. 14 No. 1, pp. 129-47.

Kulić, V. (2013), "National, supranational, international: New Belgrade and the symbolic construction of a socialist capital", Nationalities Papers: The Journal of Nationalism and Ethnicity, Vol. 41 No. 1, pp. 35-63.

Kulić, V. (2014), "New Belgrade and socialist Yugoslavia's three globalisations", International Journal for History, Culture and Modernity, Vol. 2 No. 2, pp. 125-53.

Le Normand, B. (2014), Designing Tito's Capital: Urban Planning, Modernism, and Socialism in Belgrade, University of Pittsburgh Press, Pittsburgh, PA.

Lefebvre, H. (1947), Critique de la vie quotidienne, Editions Bernard Grasset, Paris.

Leiper, N. (1990), "Tourist attraction systems”, Annals of Tourism Research, Vol. 17 No. 3, pp. 367-84.

Lew, A.A. (1987), "A framework of tourist attraction research", Annals of Tourism Research, Vol. 14 No. 4, pp. 553-75.

Lew, A.A. (2014), "Introduction: tourist attractions: places, spaces, and forms", in Lew, A.A., Hall, C.M. and Williams, A.M. (Eds), The Wiley Blackwell Companion to Tourism, John Wiley \& Sons, Chichester, pp. 363-8.

Light, D. (2000), "Gazing on communism: heritage tourism and post-communist identities in Germany, Hungary and Romania”, Tourism Geographies, Vol. 2 No. 2, pp. 157-76.

Loukaki, A. (1997), "Whose genius loci? Contrasting interpretations of the sacred rock of the Athenian Acropolis", Annals of the Association of American Geographers, Vol. 87 No. 2, pp. 306-29.

McCarthy, F. (2017), "A beautiful new map celebrates the disappearing Brutalist architecture of Belgrade", available at: www.lonelyplanet.com/news/2017/06/29/map-brutalist-architecture-belgrade/ (accessed December 5, 2017). 
Maitland, R. (2010), "Everyday life as a creative experience in cities", International Journal of Culture, Tourism and Hospitality Research, Vol. 4 No. 3, pp. 176-85.

Maoz, D. (2006), "The mutual gaze”, Annals of Tourism Research, Vol. 33 No. 1, pp. 221-39.

Mecanov, D. (2010), "Valorizacija arhitekture stambenih zgrada iz perioda moderne", Nasleđe, Vol. XI, pp. 79-101.

Mowforth, M. and Munt, I. (2015), Tourism and Sustainability: Development, Globalisation and New Tourism in the Third World, Routledge, New York, NY and London.

Novelli, M. (Ed.) (2005), Niche Tourism: Contemporary Issues, Trends and Cases, Elsevier, Burlington, MA.

Novy, J. and Huning, S. (2008), "New tourism (Areas) in the New Berlin", in Maitland, R. and Newman, P. (Eds), World Tourism Cities. Developing Tourism Off the Beaten Track, Routledge, London, pp. 87-108.

Perović, M. (2008), Iskustva prošlosti, Građevinska knjiga, Beograd.

Peručić, D. and Puh, B. (2012), "Attitudes of citizens of Dubrovnik towards the impact of cruise tourism on Dubrovnik", Tourism and Hospitality Management, Vol. 18 No. 2, pp. 213-28.

Rabotić, B. (2010), "Tourist guides in contemporary tourism", International Conference on Tourism and Environment, Philip Noel-Baker University, Sarajevo, March 4-5, pp. 353-64.

Rabotić, B. (2012), "The tomb as tourist attraction: the house of flowers in Belgrade", 1st Belgrade International Tourism Conference: Contemporary Tourism - Wishes \& Opportunities, Conference Proceedings, pp. 249-62.

Seaton, A. (2002), "Tourism as metempsychosis and metensomatosis: the personae of eternal recurrence", in Dann, G.M.S. (Ed.), The Tourist as a Metaphor for the Social World, CAB International, Wallingford, pp. 135-168.

Simić, M. (2014), Kosmopolitska čežnja: etnografija srpskog postsocijalizma, CSK FPN i Čigoja štampa, Beograd.

Smith, L. (2006), Uses of Heritage, Routledge, London.

Somborski, M. (1951), "Razvoj Beograda između dva rata”, in Minić, O. (Ed.), Beograd: Generalni urbanistički plan 1950, Izvršni odbor N.O. Beograda, Beograd, pp. 40-51.

Stock, M. and Lucas, L. (2012), "La double révolution urbaine du tourisme", Espaces et sociétés, Vol. 151 No. 3, pp. 15-30.

Tierney, P. (2016), "Belgrade: where to explore the Serbian capital's Brutalist architecture”, available at: www. standard.co.uk/lifestyle/travel/belgrade-where-to-explore-the-serbian-capitals-brutalist-architecture-a32 53406.html (accessed December 5, 2017).

Todorović, N. and Jovičić, D. (2016), "Motivational factors of youth tourists visiting Belgrade", Journal of the Geographical Institute "Jovan Cvijic”, Vol. 66 No. 2, pp. 273-89.

Tuan, Y.F. (1977), Space and Place: The Perspective of Experience, Uni of Minnesota Press, Minneapolis, MN. Urry, J. (1995), Consuming Places, Routledge, London and New York, NY.

Urry, J. and Larsen, L. (2011), The Tourist Gaze 3.0, Sage, London.

Velikonja, M. (2009), "Lost in transition: nostalgia for socialism in post-socialist countries", East European Politics and Societies, Vol. 23 No. 4, pp. 535-51.

Waley, P. (2011), "From modernist to market urbanism: the transformation of New Belgrade", Planning Perspectives, Vol. 26 No. 2, pp. 209-35.

Williams, R. (1958), Culture and Society, Chatto and Windus.

Williams, S. and Lew, A. (2014), Tourism Geography: Critical Understandings of Place, Space and Experience, Routledge, London and New York, NY.

Young, M. (1999), "The social construction of tourist places", Australian Geographer, Vol. 30 No. 3, pp. 373-89.

\section{Web references}

360Belgrade, available at: www.360beograd.com/

Belgrade Free Tour, available at: http://belgradefreetour.com/ 
Beligrad, available at: www.beligrad.com/Belgrade.jpg

City of Belgrade, available at: www.beograd.rs/

Lonely Planet News, available at: www.lonelyplanet.com/news/

Still in Belgrade, available at: http://stillinbelgrade.com/

Tačka komunikacije, available at: http://tackakomunikacije.org

Tourist Organisation of Belgrade, available at: www.tob.rs

Visit Belgrade, available at: http://visitserbiabelgrade.com

\section{Further reading}

Robinson, M. (2005), "Foreward", in Novelli, M. (Ed.), Niche Tourism: Contemporary Issues, Trends and Cases, Elsevier, Burlington, MA, pp. 3-14.

\section{Corresponding author}

Sanja Iguman can be contacted at: sanja.iguman@unibg.it

For instructions on how to order reprints of this article, please visit our website: 